\title{
Y Chromosomal STR Polymorphism in Northern Chinese Populations
}

\author{
LIHONG ZHENG ${ }^{1,2}$, HAIMING SUN ${ }^{1}$, JINGWEI WANG ${ }^{1}$, SHILIN LI $^{3}$, JING BAI $^{1}$, \\ YAN JIN ${ }^{1}$, YANG YU ${ }^{1}$, FENG CHEN ${ }^{1}$, LI JIN ${ }^{3}$ and SONGBIN FU ${ }^{1,4, *}$
}

\author{
${ }^{1}$ Laboratory of Medical Genetics, Harbin Medical University, Harbin, 150081, China \\ ${ }^{2}$ Biological genetics department, Qiqihar Medical University, Qiqihar, 161006, China \\ ${ }^{3}$ MOE Key Laboratory of Contemporary Anthropology, Fudan University, Shanghai, 200433, China \\ ${ }^{4}$ Bio-pharmaceutical Key Laboratory of Heilongjiang Province, Harbin 150081, China
}

\begin{abstract}
Y chromosomal STRs show sufficient variability among individuals in a population and a high degree of geographical differentiation, such that their polymorphic character makes them especially suited for population genetic studies. To investigate the polymorphism of a set of $17 \mathrm{Y}$-STR loci in northern China, we genotyped the $17 \mathrm{Y}$ chromosomal STR loci in a population sample of 377 unrelated males from eight ethnic populations in northern China. We calculated the haplotype frequencies, Rst value and carried out the analysis of molecular variance (AMOVA). We then drew the multidimensional scaling analysis (MDS) plot and phylogenetic tree based on the Rst value. All populations showed a high level of haplotype diversity, with low inter-population variance as measured by an analysis of molecular variance. However, the genetic distances were significant when the eight populations were compared to other populations. By MDS and the phylogenetic tree, we found that the eight populations had a close relationship and Xibo had a northeast origination.
\end{abstract}

Key terms: China; population; STR; Y chromosome.

\section{INTRODUCTION}

The Y chromosome is inherited from father to son and the majority of its DNA lacks recombination. Therefore, all descendants of a male lineage share a common $Y$ chromosomal haplotype in the nonrecombining region, unless a mutation alters the haplotype. Y chromosomal STRs show sufficient variability among individuals in a population and a high degree of geographical differentiation (Jobling and Tyler-Smith 1995). Thus, their polymorphic character makes them especially suited for forensic, genealogical and population genetic studies (de Knijff et al. 1997; Gusmao et al. 2006; Jobling et al. 1997; Schultes et al. 1999).

The Y-STR Haplotype Reference database has been established for populations around the world (Kayser et al. 2002; Lessig et al. 2003; Roewer et al. 2001; Willuweit and Roewer 2007). The minimal haplotype, which consists of the loci DYS19, DYS389I, DYS389II, DYS390, DYS391, DYS392, DYS393 and DYS385, can distinguish approximately $76.1-95.5 \%$ of male individuals in various populations (Kayser et al. 2002; Roewer et al. 2001; Schoske et al. 2004). Despite the utility of the minimal haplotype, additional Y-STR loci are required to improve the ability to distinguish different paternal lineages. Also, empirical studies of the other Y-STR loci are needed to provide an efficient marker set with sufficient power of discrimination (Gusmao et al. 2006). Recently, a set of 17 Y-STR loci had been analyzed in some populations and exhibited

\footnotetext{
* Correspondence Author: Dr. SONGBIN FU, Laboratory of Medical Genetics, Harbin Medical University, Baojian Road 157, Nangang District, Harbin 150081, China, Tel: +86-451-86674798; Fax: +86-451-86674798, Email: fusb@ems.hrbmu.edu.cn, fusongbin@yahoo.com
} 
a high degree of haplotype diversity (Huang et al. 2008; Kumagai et al. 2007; Pontes et al. 2007), while the polymorphism of these loci in the northern China population was unknown. Here, we present haplotype analysis and genetic tests of these $17 \mathrm{Y}$ STR loci in eight ethnic populations from northern China to explore the genetic relationships of these populations.

\section{MATERIALS AND METHODS}

\section{DNA Samples:}

A total of 377 unrelated male subjects were randomly selected from eight ethnic groups in northern China (Fig. 1). The male subjects were obtained from ethnic minority settlements. Prior to sampling, a questionnaire had been filled in by each participant regarding the ethnic nature of his parents and grandparents. Only the ones whose parents and grandparents were from the same minority were included in this study. For the eight groups involved in the present study, Xibo was sampled from Xinjiang Municipality (northwest China); while the other ethnic groups came from Heilongjiang, Jinlin, Liaoning province and the Inner Mongolia Municipality (northeast China), respectively. Of the 377 individuals, 50 were Mongol, 71 were Man, 48 were Hezhen, 73 were Korean, 50 were Ewenk, 27 was Oroqen, 30 were Daur and 28 were Xibo. Details are listed in table 1. Blood samples were collected from randomly selected individuals in each ethnic group. All subjects were resident in their own hometown and everyone was the offspring of a non-sanguineous marriage of members of the same nationality for within at least three generations. Informed consent was obtained from all participants in this study. DNA was extracted from peripheral blood samples anticoagulated with ACD by the standard phenol-chloroform extraction method.

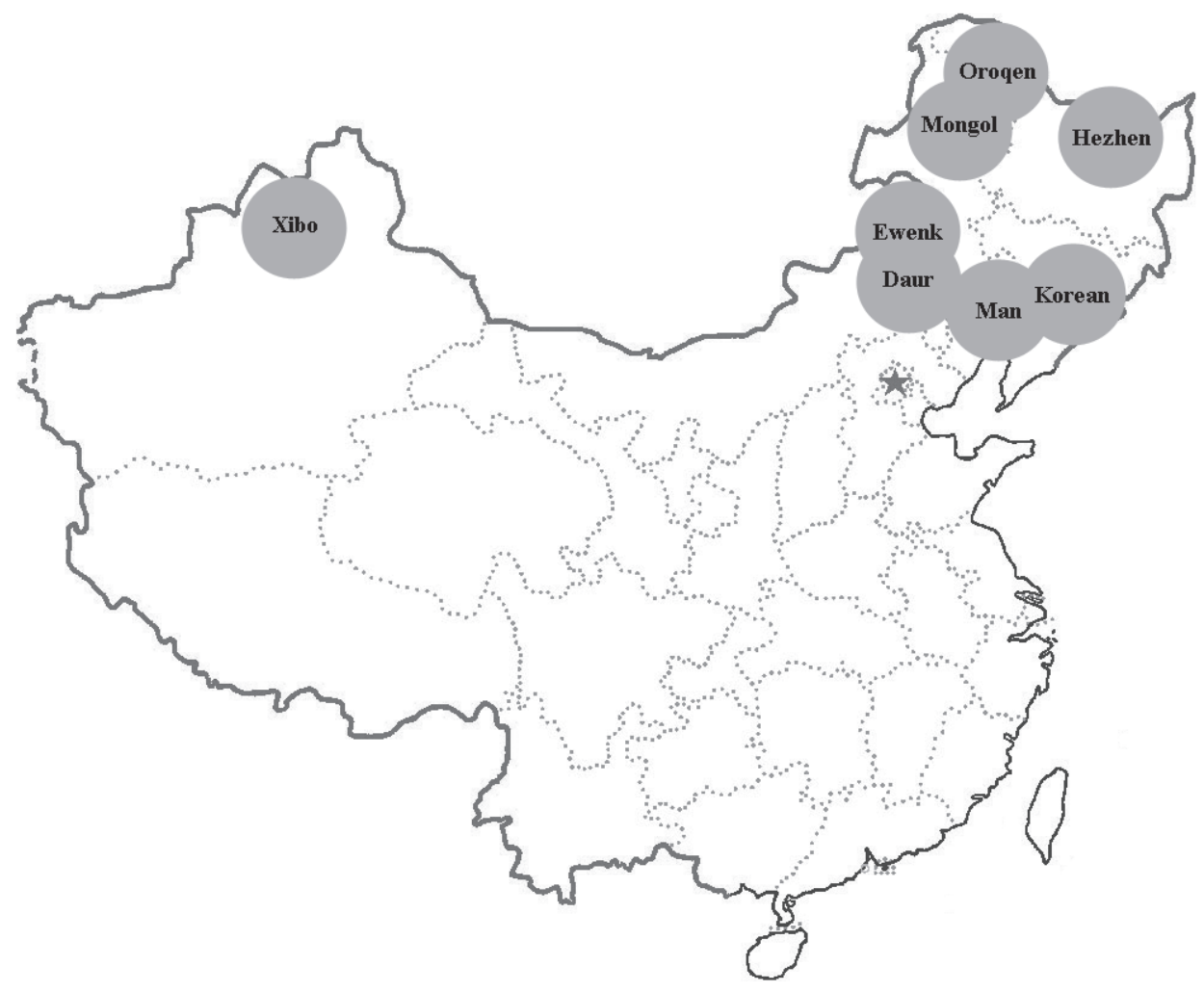

Figure 1: Geographic distribution of the study populations in China. 


\section{Y-STR Genotyping:}

All samples were genotyped the 17 Y-STR loci (DYS19, DYS385a, DYS385b, DYS389I, DYS389II, DYS390, DYS391, DYS392, DYS393, DYS437, DYS438, DYS439, DYS448, DYS456, DYS458, DYS635 and GATA H4) by the AmpFlSTR ${ }^{\circledR}$ Y-filer ${ }^{\mathrm{TM}}$ PCR Amplification kit (Applied Biosystems, Foster City, CA) according to the manufacturer's instructions. The amplified products were analyzed with an ABI PRISM 3130XL Genetic Analyzer (Applied Biosystems). The genotyping designations were based on comparison with allelic ladders included in the $\mathrm{Y}$-filer ${ }^{\mathrm{TM}}$ kit using GeneMapper 4.0 software (Applied Biosystems). We used the control DNA samples and allelic ladders provided by the manufacture of the kit, and followed the International Society for Forensic Genetics (ISFG) guidelines for STR analysis.

\section{Analysis of data:}

The number of haplotypes was counted for each population. Haplotype diversity $(H)$ was calculated as $H=n\left(1-\sum \pi^{2}\right) /(n-1)$, where $\pi$ is the frequency of the $i$ th haplotype and $n$ is the number of samples (Nei 1996). The discrimination capacity $(D)$ was determined by dividing the number of haplotypes by the number of individuals in each population (Gene et al. 1999).

Genetic relationships between the eight populations, based on the 17 Y-STR loci haplotypes, were further explored by analysis of molecular variance (AMOVA), as implemented in Arlequin 3.01 (Excoffier et al. 2005) (http: //cmpg.unibe.ch/software/ arlequin3/). Subsequently, the haplotypes of these populations were compared to published data from eight populations: Tibetan, $n=167$ (Zhu et al. 2008); Taiwanese, $\mathrm{n}=200$ (Huang et al. 2008); Portuguese, $\mathrm{n}=175$ (Pontes et al. 2007); Serbian, $\mathrm{n}=185$ (Veselinovic et al. 2008); Shandong Han, $\mathrm{n}=131$ (Yan et al. 2007); Japanese, $n=1079$ (Mizuno et al. 2008); Western Russian, $\mathrm{n}=545$ (Roewer et al. 2008) and Chinese Hui, $\mathrm{n}=143$ (Guo et al. 2008), with Rst (the index of the population pairwise genetic distance), which is analogous to $F s t$ but is based on a stepwise mutation model. AMOVA and the $R s t$ values were assessed by permutation tests with 10,000 permutations. Population relationships on the basis of the Rst values were determined by multidimensional scaling analysis (MDS) as implemented in Statistica (StatSoft Inc., Tulsa, USA). Based on the Rst genetic distances, phylogenetic tree was constructed based on the Neighbor-Joining method using the MEGA software ver.4.1 (Kumar et al. 2008).

\section{RESULTS}

A total of 377 unrelated males from eight northern China populations were investigated in this study and 361 different haplotypes were detected. Two haplotypes occurred three times, 12 occurred twice and 347 were unique (Supplementary Table 1). The discrimination capacity of these 17 loci in the total samples was 0.958, and the haplotype diversity value was 0.9991 (see Table 2).

AMOVA of the eight ethnic populations in northern China indicated that $96.36 \%$ of the variation was found within populations, whereas only $3.64 \%$ was among populations (Table 3 ).

We obtained data for the 17 loci haplotypes of another eight populations from the literature. We carried out the Rst analysis for the total 16 populations. The pairwise Rst results showed that there were significant differences between the northern China populations and the other populations $(P<0.001$, Supplementary Table 2$)$. On the basis of pairwise Rst values, we drew the MDS plot to learn the relationships of these populations. The results displayed a close relationship among the eight northern China populations, with an elevated distance to the other Asian and European populations (Fig. 2). We then constructed the phylogenetic tree by the MEGA. The results showed that the eight northern China populations and Shandong Han were in a clade, while the other populations were in another clade (Fig. 3). 
TABLE 1

Details of the eight populations

\begin{tabular}{lccc}
\hline Population & Number & Sampling place & Location (longitude, latitude) \\
\hline Mongol & 50 & Hailar, Inner Mongolia Municipality & $126.0,51.0$ \\
Man & 71 & Xiuyan, Liaoning Province & $123.2,40.2$ \\
Hezhen & 48 & Tongjiang, Heilongjiang Province & $132.5,46.7$ \\
Korean & 73 & Yanji, Jilin Province & $121.4,40.2$ \\
Ewenk & 50 & Molidawa, Inner Mongolia Province & $118.6,48.0$ \\
Oroqen & 27 & Arlihe, Inner Mongolia Province & $131.0,53.5$ \\
Daur & 30 & Molidawa, Inner Mongolia Province & $118.6,40.8$ \\
Xibo & 28 & Yili, Xinjiang Municipality & $80.5,43.3$ \\
\hline
\end{tabular}

TABLE 2

Diversity parameters of 17 Y-STRs in eight different Chinese populations

\begin{tabular}{lcccc}
\hline Population & Number & diff Ht & $D$ & $h$ \\
\hline Mongol & 50 & 48 & 0.960 & 0.9992 \\
Man & 71 & 70 & 0.986 & 0.9998 \\
Hezhen & 48 & 39 & 0.813 & 0.9952 \\
Korean & 73 & 71 & 0.973 & 0.9996 \\
Ewenk & 50 & 50 & 1.000 & 1.0000 \\
Oroqen & 27 & 27 & 1.000 & 1.0000 \\
Daur & 30 & 28 & 0.967 & 0.9989 \\
Xibo & 28 & 361 & 1.000 & 1.0000 \\
Total & 377 & & 0.958 & 0.9991 \\
\hline
\end{tabular}

Diff Ht: number of different haplotypes; $D$ : discrimination capacity; $h$ : haplotype diversity

TABLE 3

Analysis of molecular variance in the eight populations

\begin{tabular}{lccc}
\hline Source of variation & Sum of squares & Variance components & Percentage of variation \\
\hline Among populations & 103.257 & 0.203 & 3.64 \\
Within populations & 1982.544 & 5.373 & 96.36 \\
Total & 2085.801 & 5.576 & \\
\hline
\end{tabular}



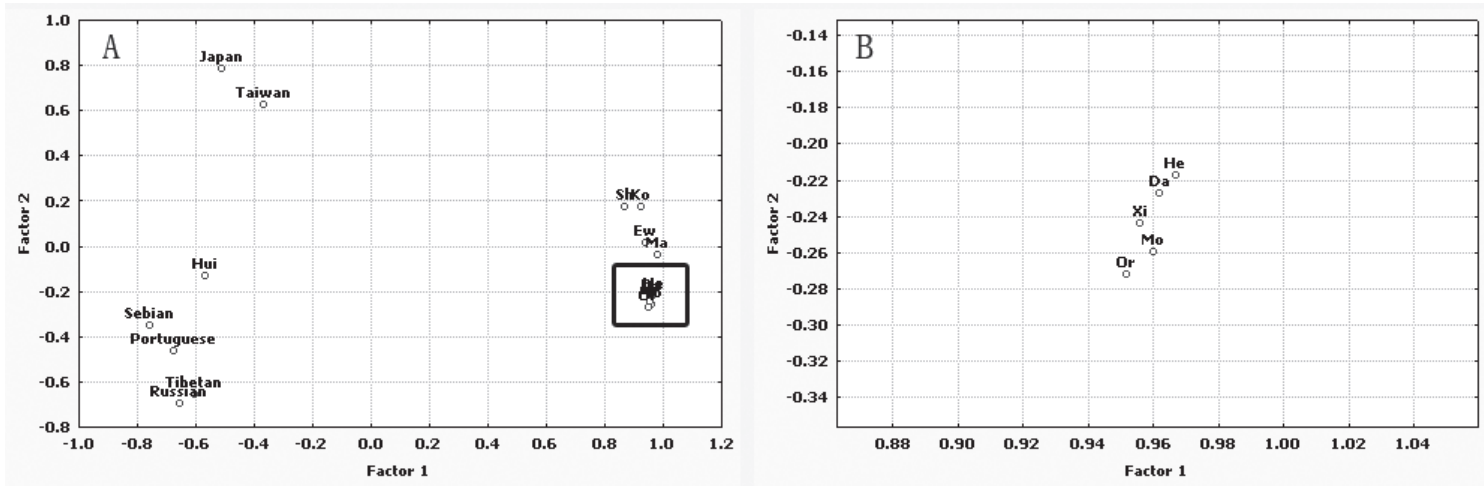

Figure 2: Multidimensional scaling analysis (MDS) plot of the northern China populations and eight other populations, from pairwise Rst values. B is an enlargement of the square in A. Acronymas was as follows: Ma-Man; Mo-Mongol; He-Hezhen; Ko-Korean; Or-Oroquen; Da-Daur; Xi-Xibo; Ew-Ewenk and Sh-Shandong Han.

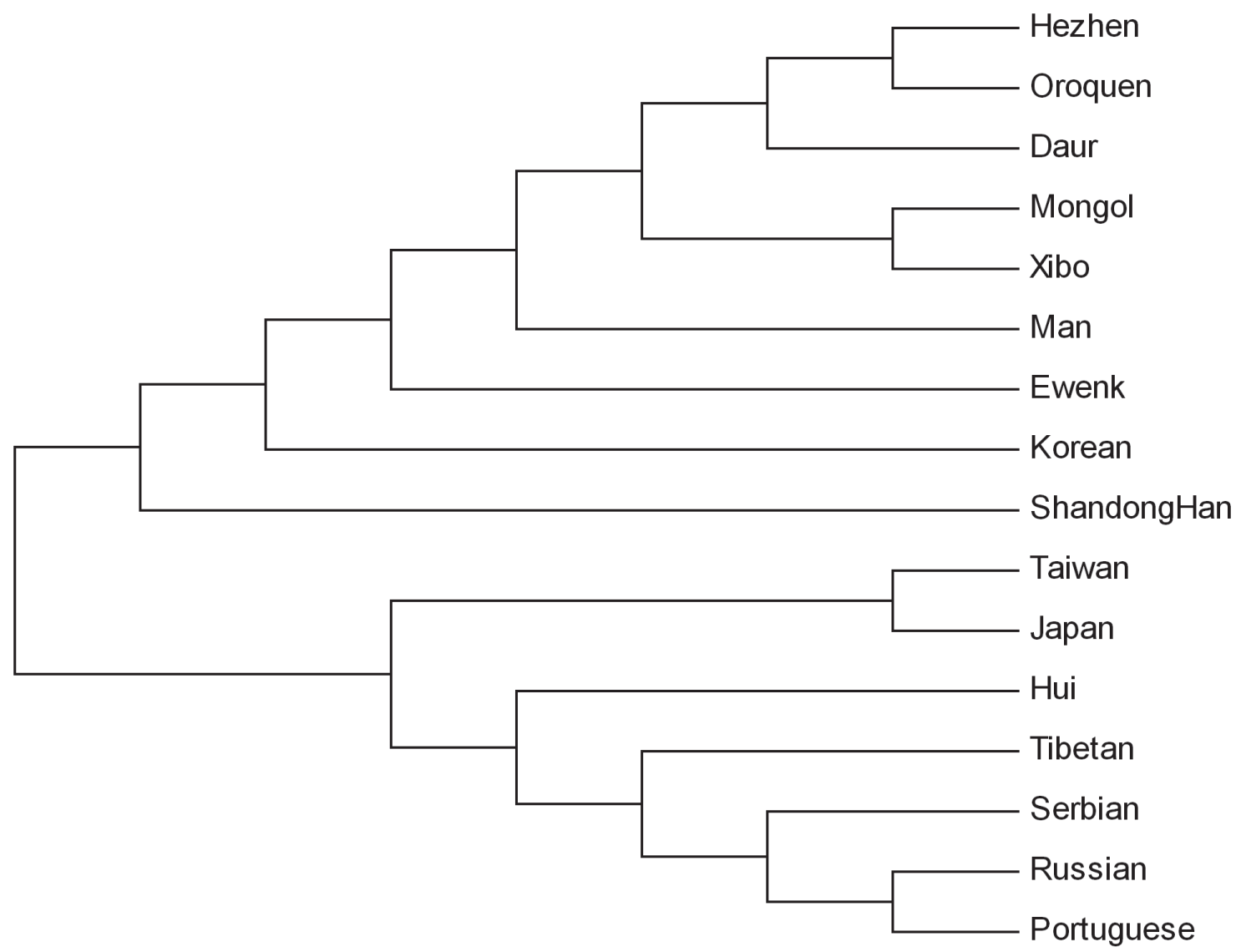

Figure 3: Phylogenetic tree of 16 populations based on the Rst values 


\section{DISCUSSION}

Human Y-linked polymorphisms in the non-pseudoautosomal portion of the $\mathrm{Y}$ chromosome are haploid inherited with paternal lineage. This part of $Y$ chromosome lacks recombination, which is the same as mitochondrial DNA, and is passed down from father to son unchanged except for mutations. The use of $Y$ chromosome polymorphisms, especially YSTR, has become commonplace in an application of human evolutionary study and population history research (Huang et al. 2008; Jobling et al. 1997; Kumagai et al. 2007; Mertens et al. 2007; Parkin et al. 2006), as well as in a variety of forensic situations for mixture analysis and paternity test (Diederiche et al. 2005; Hall and Ballantyne 2003; Hanson and Ballantyne 2004; Jobling et al. 1997).

In this study we genotyped 17 Y-STR loci in 377 male subjects from eight northern China populations. The results showed that there were 361 haplotypes in these 377 individuals, and most haplotypes appeared only once. There was only one shared haplotype among these populations, which appeared in two populations (Korean and Oroqen). These 17 loci had a high level of haplotype diversity and discrimination capacity in these eight populations (Table 2 ). These results indicated that this set of loci had a high level of diversity in northern China and that they were suitable for forensic discrimination.

The results of the AMOVA showed that $96.36 \%$ of the variation was found within populations, whereas only $3.64 \%$ was among populations. These results showed that the eight populations had a close relationship, which is in accordance with other studies carried on the basis of the classical genetic markers or the uniparental markers (Ma et al. 2005; Mao et al. 2008; Xue et al. 2005). To obtain a more comprehensive picture of the genetic structure of these populations, we obtained the Y-STR data of the other eight populations from Asia and Europe and carried out Rst analysis for all 16 populations. The results showed that the Rst value was low among the northern China populations, while the difference between northern China and other populations was large (Supplementary Table 2). An MDS plot based on pairwise Rst values showed the northern China populations formed a close knit group. For the other populations, Shandong Han was close to the northern China population, while the other populations were far away from the core group. Shandong province is near northeast China so this could be the cause of their close relationship. As demonstrated in the MDS plot, Taiwanese and Japanese had a close genetic relationship. Hui was clustered with the Europe populations, Hui are descended from Arab and Persian Muslim traders who settled in China (Dillon 1999), so the patrilineal genetic structure is similar to that of Europeans. The result of the phylogenetic tree was in accordance with the MDS: Shandong Han was clustered with the eight northern China populations, Taiwanese and Japanese were in a sub-clade, Hui, Tibetan and three Europe populations were in a sub-clade.

From the MDS plot and the phylogenetic tree, we know that the distribution pattern was in good agreement with the geographic locations or the ethno-origins of these populations. The results showed that the haplotypes of these 17 loci had a good geographical characteristic and that the eight northern China populations had a close relationship.

In the eight populations, Xibo was sampled from Xinjiang province, which is located in the northwestern China, while the others are from the northeast. From the results of MSD plot, we found that Xibo was mixed with the northeast populations. In the phylogenetic tree, Xibo had the closest relationship to Mongols. The Xibo originated in northeastern China, where their ancestry can be traced for at least 3000 years. In 1764, about 1020 soldiers, together with 4000 dependants, were sent to defend the border of the northwestern province of Xinjiang and their descendants have remained there ever since (Ruofu 1994). They speak a language related to Man, reflecting their northeastern origins, quite distinct from the Uygur language spoken in the northwest. Our findings also 
demonstrated the northeastern origin of the Xibo.

In this study, we examined 17 Y-STR loci in eight northern China populations and carried out the analysis of molecular variance, $R s t$, multidimensional scaling analysis and constructed the phylogenetic tree. By these analyses, we found that the eight populations had a close relationship and that the Xibo have a northeastern origin.

\section{ACKNOWLEDGEMENTS}

We thank all the volunteers for providing blood samples for this study. The project was supported by National Natural Science Foundation of China (No. 30671146).

\section{REFERENCES}

DE KNIJFF P, KAYSER M, CAGLIA A, CORACH D, FRETWELL N, GEHRIG C, GRAZIOSI G, HEIDORN F, HERRMANN S, HERZOG B, HIDDING M, HONDA K, JOBLING M, KRAWCZAK M, LEIM K, MEUSER S, MEYER E, OESTERREICH W, PANDYA A, PARSON W, PENACINO G, PEREZLEZAUN A, PICCININI A, PRINZ M, ROEWER L, et al. (1997) Chromosome Y microsatellites: population genetic and evolutionary aspects. Int J Legal Med 110: 134-49

DIEDERICHE M, MARTIN P, AMORIM A, CORTEREAL F, GUSMAO L (2005) A case of double alleles at three Y-STR loci: forensic implications. Int J Legal Med 119: 223-5

DILLON M (1999) CHINA'S MUSLIM HUI COMMUNITY : MIGRATION, SETTLEMENT AND SECTS. CURZON PRESS, LONDON EXCOFFIER L, LAVAL G, SCHNEIDER S (2005) Arlequin (version 3.0): An integrated software package for population genetics data analysis. Evol Bioinform Online 1: 47-50

GENE M, BORREGO N, XIFRO A, PIQUE E, MORENO P, HUGUET E (1999) Haplotype frequencies of eight Y-chromosome STR loci in Barcelona (North-East Spain). Int J Legal Med 112: 403-5

GUO H, YAN J, JIAO Z, TANG H, ZHANG Q, ZHAO L, HU N, LI H, LIU Y (2008) Genetic polymorphisms for 17 Y-chromosomal STRs haplotypes in Chinese Hui population. Leg Med (Tokyo) 10: 163-9

GUSMAO L, BUTLER JM, CARRACEDO A, GILL P, KAYSER M, MAYR WR, MORLING N, PRINZ M, ROEWER L, TYLER-SMITH C, SCHNEIDER PM (2006) DNA Commission of the International Society of Forensic Genetics (ISFG): an update of the recommendations on the use of Y-STRs in forensic analysis. Int J Legal Med 120: 191-200

HALL A, BALLANTYNE J (2003) The development of an 18-locus Y-STR system for forensic casework. Anal Bioanal Chem 376: 1234-46

HANSON EK, BALLANTYNE J (2004) A highly discriminating 21 locus Y-STR "megaplex" system designed to augment the minimal haplotype loci for forensic casework. J Forensic Sci 49: 40-51

HUANG TY, HSU YT, LI JM, CHUNG JH, SHUN CT (2008) Polymorphism of 17 Y-STR loci in Taiwan population. Forensic Sci Int 174: 249-54

JOBLING MA, PANDYA A, TYLER-SMITH C (1997) The $\mathrm{Y}$ chromosome in forensic analysis and paternity testing. Int J Legal Med 110: 118-24

JOBLING MA, TYLER-SMITH C (1995) Fathers and sons: the Y chromosome and human evolution. Trends Genet 11: 449-56

KAYSER M, BRAUER S, WILLUWEIT S, SCHADLICH H, BATZER MA, ZAWACKI J, PRINZ M, ROEWER L, STONEKING M (2002) Online Y-chromosomal short tandem repeat haplotype reference database (YHRD) for U.S. populations. J Forensic Sci 47: 513-9

KUMAGAI R, KUMAGAI A, SAIGUSA K, AOKI Y (2007) Haplotype analysis of 17 Y-STR loci in a Japanese population. Forensic Sci Int 172: 72-8

KUMAR S, NEI M, DUDLEY J, TAMURA K (2008) MEGA: a biologist-centric software for evolutionary analysis of DNA and protein sequences. Brief Bioinform 9: 299-306

LESSIG R, WILLUWEIT S, KRAWCZAK M, WU FC, PU CE, KIM W, HENKE L, HENKE J, MIRANDA J, HIDDING M, BENECKE M, SCHMITT C, MAGNO M, CALACAL G, DELFIN FC, DE UNGRIA MC, ELIAS S, AUGUSTIN C, TUN Z, HONDA K, KAYSER M, GUSMAO L, AMORIM A, ALVES C, HOU Y, KEYSER C, LUDES B, KLINTSCHAR M, IMMEL UD, REICHENPFADER B, ZAHAROVA B, ROEWER L (2003) Asian online Y-STR Haplotype Reference Database. Leg Med (Tokyo) 5 Suppl 1: S160-3

MA LL, XUE YL, LIU Y, WANG Z, CUI XB, LI P, FU SB (2005) Polymorphism study of seven SNPs at ADH genes in 15 Chinese populations. Hereditas 142: 103111

MAO RF, FAN YH, CHEN F, FU SB (2008) Genetic polymorphism of MTHFR G1793A in Chinese populations. European Journal of Epidemiology 23: 363-368

MERTENS G, JEHAES E, LEIJNEN G, RAND S, JACOBS W, VAN MARCK E (2007) Twelve-locus YSTR haplotypes in the Flemish population. J Forensic Sci 52: 755-7

MIZUNO N, NAKAHARA H, SEKIGUCHI K, YOSHIDA K, NAKANO M, KASAI K (2008) 16 Y chromosomal STR haplotypes in Japanese. Forensic Sci Int 174: 71-6

NEI M (1996) Phylogenetic analysis in molecular evolutionary genetics. Annu Rev Genet 30: 371-403

PARKIN EJ, KRAAYENBRINK T, VAN DRIEM GL, TSHERING OF GASELO K, DE KNIJFF P, JOBLING MA (2006) 26-Locus Y-STR typing in a Bhutanese population sample. Forensic Sci Int 161: 1-7

PONTES ML, CAINE L, ABRANTES D, LIMA G, PINHEIRO MF (2007) Allele frequencies and population data for $17 \mathrm{Y}$-STR loci (AmpFlSTR Y-filer) in a Northern Portuguese population sample. Forensic Sci Int 170: 62-7

ROEWER L, KRAWCZAK M, WILLUWEIT S, NAGY M, ALVES C, AMORIM A, ANSLINGER K, AUGUSTIN C, BETZ A, BOSCH E, CAGLIA A, CARRACEDO A, CORACH D, DEKAIRELLE AF, DOBOSZ T, DUPUY BM, FUREDI S, GEHRIG C, GUSMAO L, HENKE J, HENKE L, HIDDING M, HOHOFF C, HOSTE B, JOBLING MA, KARGEL HJ, DE KNIJFF P, LESSIG $R$, LIEBEHERR E, LORENTE M, MARTINEZJARRETA B, NIEVAS P, NOWAK M, PARSON W, PASCALI VL, PENACINO G, PLOSKI R, ROLF B, 
SALA A, SCHMIDT U, SCHMITT C, SCHNEIDER PM, SZIBOR R, TEIFEL-GREDING J, KAYSER M (2001) Online reference database of European Ychromosomal short tandem repeat (STR) haplotypes. Forensic Sci Int 118: 106-13

ROEWER L, WILLUWEIT S, KRUGER C, NAGY M, RYCHKOV S, MOROZOWA I, NAUMOVA O, SCHNEIDER Y, ZHUKOVA O, STONEKING M, NASIDZE I (2008) Analysis of Y chromosome STR haplotypes in the European part of Russia reveals high diversities but non-significant genetic distances between populations. Int J Legal Med 122: 219-23

RUOFU D (1994) Ethnic groups in China. Sciense Publishing House,Beijing.

SCHOSKE R, VALLONE PM, KLINE MC, REDMAN JW, BUTLER JM (2004) High-throughput Y-STR typing of U.S. populations with 27 regions of the Y chromosome using two multiplex PCR assays. Forensic Sci Int 139: 107-21

SCHULTES T, HUMMEL S, HERRMANN B (1999) Amplification of Y-chromosomal STRs from ancient skeletal material. Hum Genet 104: 164-6

VESELINOVIC IS, ZGONJANIN DM, MALETIN MP,
STOJKOVIC O, DJURENDIC-BRENESEL M, VUKOVIC RM, TASIC MM (2008) Allele frequencies and population data for $17 \mathrm{Y}$-chromosome STR loci in a Serbian population sample from Vojvodina province. Forensic Sci Int 176: e23-8

WILLUWEIT S, ROEWER L (2007) Y chromosome haplotype reference database (YHRD): Update. Forensic Science International: Genetics 1: 83-87

XUE YL, ZERJAL T, BAO WD, ZHU SL, LIM SK, SHU QF, XU JJ, DU RF, FU SB, LI P, YANG HM, TYLERSMITH C (2005) Recent spread of a Y-chromosomal lineage in northern China and Mongolia. American Journal of Human Genetics 77: 1112-1116

YAN J, TANG H, LIU Y, JING Y, JIAO Z, ZHANG Q, GAO J, SHANG L, GUO H, YU J (2007) Genetic polymorphisms of 17 Y-STRs haplotypes in Chinese Han population residing in Shandong province of China. Leg Med (Tokyo) 9: 196-202

ZHU B, WU Y, SHEN C, YANG T, DENG Y, XUN X, TIAN Y, YAN J, LI T (2008) Genetic analysis of 17 Ychromosomal STRs haplotypes of Chinese Tibetan ethnic group residing in Qinghai province of China. Forensic Sci Int 175: 238-43 